\title{
The Zebrafish Cerebellum
}

Jan Kaslin $^{1}$ and Michael Brand ${ }^{2}$

1) Australian Regenerative Medicine Institute, Monash University, Wellington road, Bld 75, Clayton, Victoria, 3800, Melbourne, Australia

2) Biotechnology Center and Center for Regenerative Therapies Dresden, Dresden University of Technology, Tatzberg 47, 01307, Germany

Corresponding authors: jan.kaslin@monash.edu, michael.brand@biotec.tu-dresden.de

Keywords: zebrafish, teleost, fish, adult neurogenesis, mutant, screening, eurydendroid cell, genetic model, cerebellar development, morphogenesis, mid-hindbrain-boundary, isthmic organizer, in vivo imaging

\section{Introduction}

The rapid transparent ex utero development in zebrafish allows direct access and precise visualization of all the major events in cerebellar development. The superficial position of the cerebellar primoridum and cerebellum further facilitates in vivo imaging of cerebellar structures and developmental events at single cell resolution. Furthermore, zebrafish is amenable to high-throughput screening techniques and forward genetics because of its fecundity and easy keeping. Forward genetics screens in zebrafish have resulted in several isolated cerebellar mutants and substantially contributed to the understanding of the genetic networks involved in hindbrain development (Bae et al., 2009, Brand et al., 1996). Recent developments in genetic tools, including the use of site specific recombinases, efficient transgenesis, inducible gene expression systems, and the targeted genome lesioning technologies TALEN and Cas9/CRISPR has opened up new avenues to manipulate and edit the genome of zebrafish (Hans et al., 2009, Scott, 2009, Suster et al., 2009, Goll et al., 2009, Hwang et al., 2013, Sander et al., 2011, Huang et al., 2011, Bedell et al., 2012). These tools enable the use of genome-wide genetic approaches, such as enhancer/exon traps and cell specific temporal control of gene expression in zebrafish. Several seminal papers have used these technologies to successfully elucidate mechanisms involved in the morphogenesis, neurogenesis and cell migration in the cerebellum (Bae et al., 2009, Chaplin et al., Hans et al., 2009, Volkmann et al., Volkmann et al., 2008). In addition, the use of genetically encoded sensors and probes that allows detection and manipulation of neuronal activity using optical methods have open up new means to study the physiology and function of the cerebellum (Simmich et al., 2012, Matsui et al., 2014). Taken together, these features have allowed zebrafish to emerge as a complete model for studies of molecular, cellular and physiological mechanisms involved in cerebellar development and function at both cell and circuit level.

\section{The cerebellar anatomy and architecture}

The general organization and cellular architecture of the cerebellum is highly conserved in vertebrates. The cerebellum of all jawed vertebrates consists of a major lobe, the corpus cerebelli (cerebellar corpus) and two bilateral lobes, the auricle (also known as the vestibulocerebellum, (Figure 1 A (Altman and Bayer, 1997)). The architecture of cerebellum 
is highly similar to other vertebrates but there are some notable differences. The most striking differences are the lack of deep cerebellar nuclei and a well-defined white matter. Furthermore, the zebrafish fish have additional precerebellar and cerebelloid structures. The zebrafish cerebellum can be divided in three major parts, the valvula cerebelli, the corpus cerebelli and the vestibulolateral lobe (Figure 1 B-C, (Finger, 1983, Meek, 1998, Wullimann, 1997)). The eminentia granularis and the caudal lobe together form the vestibulolateral lobe that has been suggested to be homologous to the auricle of other vertebrates (Wullimann, 1997). The cerebellar corpus in zebrafish consists of a single folia and it has an anterior extension, the valvula cerebelli, which extends into the tectal ventricle below the optic tectum. The cerebellar corpus is laterally flanked by the eminentia granularis and posteriorly by the caudal lobe. In addition, zebrafish have extra structures associated to the cerebellum such as cerebelloid structures (cerebellar-like) and additional precerebellar nuclei that are not found in other vertebrates. Zebrafish has two precerebellar nuclei, the nucleus valvula lateralis and the nucleus paracommissuralis (Figure 1 C). The precerebellar nuclei are closely associated with the cerebellum through significant fiber projections. Cerebelloid structures are architecturally thought to be very similar to the cerebellum, although they are spatially well separated from the cerebellum. Cerebelloid structures are found in all vertebrate lineages except reptiles and birds (Bell, 2002, Bell et al., 2008). Two cerebelloid structures are found in zebrafish. In the hindbrain the medial octavolateral nucleus, eminentia granularis and the cerebellar crest (crista cerebellaris) form one cerebelloid structure. The torus longintudinalis together with the optic tectum forms the second cerebelloid structure in zebrafish. Like the cerebellum the cerebelloid structures process sensory signals, receive input from the periphery to the deep layers and parallel fiber input to the molecular layer.

The general vertebrate cerebellum consists of a three-layered cortex and an underlying white matter (Altman and Bayer, 1997). This three layered arrangement is well recognizable in in zebrafish (Figure 1 D). However, the eminentia granularis and caudal lobe consists of a single granule cell layer. In contrast, to tetrapods zebrafish lack a well-defined white matter beneath the cerebellum. In teleost fish three distinct subtypes of inhibitory neurons have been found in the cerebellar cortex: stellate, Golgi and Purkinje cells. Stellate and Golgi cells are interneurons and only project within the cerebellum. The stellate cells are scattered in the molecular cell layer of teleost fish, while Golgi cells primarily are found in the granule cell layer (Figure 1 D, (Butler A., 2005, Delgado and Schmachtenberg, 2008, Hans et al., 2009, Meek et al., 2008). In most vertebrates the Purkinje cell is the sole cell type that projects outside the cerebellum to the deep cerebellar nuclei. The deep cerebellar nuclei are located in the white matter beneath the cerebellum. In zebrafish and other teleosts this is different. Firstly, teleost fish have an additional efferent cell type in the cerebellar cortex, the eurydendroid cell, and the teleost Purkinje cell projects to the eurydenroid cells (Figure $1 \mathrm{D}$ (Nieuwenhuys et al., 1974, Alonso et al., 1992, Bae et al., 2009, Meek, 1992)). Secondly, teleost fish lack deep cerebellar nuclei. However, the eurydendroid cells directly innervate similar targets in the brain stem and spinal cord as the deep cerebellar nuclei of other vertebrates and may thus have an equivalent function (Butler A., 2005, Bae et al., 2009, Ikenaga et al., 2005, Murakami and Morita, 1987). Similar to other vertebrates abundant glutamergic granule cells are found in the granule cell layer of zebrafish (Bae et al., 2009, Kaslin et al., 2009). Other less abundant cerebellar interneuron types such as unipolar brush, Lugaro, and basket cells have not yet been identified in zebrafish.

The vertebrate cerebellum receives afferent input from two principal sources, mossy and climbing fibers (Figure 1 E,(Altman and Bayer, 1997)). In zebrafish the climbing fibers originate in the inferior olive in the caudal hindbrain and predominately terminate on the soma and the proximal dendrites of Purkinje neurons (Figure 1 E (Bae et al., 2009, Folgueira 
et al., 2006, Wullimann and Northcutt, 1988, Xue et al., 2008)). Similar to other vertebrates the mossy fiber-like pathway in teleost fish originates from multiple sources such as the spinal cord, reticular formation and tegmentum (Figure 1 E (Finger, 1978, Folgueira et al., 2006, Kani et al., Volkmann et al., Wullimann and Northcutt, 1988, Wullimann and Northcutt, 1989)). Systematic retrograde tracing experiments have not yet been undertaken in zebrafish but in agreement above mentioned studies, mossy fiber-like input from several precerebellar nuclei has been reported in juvenile zebrafish (Bae et al., 2009, Kani et al., Volkmann et al.). The cerebellar output from the eurydendroid cells in zebrafish has recently been mapped by genetic methods (Matsui et al., 2014) and is in agreement with studies from other teleosts (Folgueira et al., 2006, Ikenaga et al., 2002, Ito and Yoshimoto, 1990, Wullimann and Northcutt, 1988). Targets such as the thalamus, pretectal nuclei, tegmental nuclei and motor and premotor centers are innervated by the eurydendroid cells.

\section{Cerebellar development and neurogenesis}

The initial phase of midbrain and cerebellar development in vertebrates depends on the formation and function of the isthmic organizer which lies at the midbrain-hindbrain boundary (MHB, Figure 2). The MHB organizer formation and maintenance is defined by an intricate cascade of genetic interactions that are marked by complex temporal and spatial patterns of gene expression (Figure 2). Initially the MHB is positioned along the anterior-posterior axis early within the neural plate by the opposing boundary created by mutual repression between the transcription factors otx2 and gbx2 (Broccoli et al., 1999, Millet et al., 1999, Rhinn and Brand, 2001, Simeone, 2000). In contrast to other vertebrates, $g b x 1$ and not $g b x 2$ positions the MHB in zebrafish (Rhinn et al., 2009, Rhinn et al., 2005). At the end of gastrulation, a complex genetic network with several region-specific transcription factors such as Pax2/5 and $E n 1 / 2$, and the secreted molecules Wnt1 and Fgf8 are expressed at the $O t x / G b x$ interface (Rhinn and Brand, 2001). The secreted signals from the isthmic organizer in turn determine the development of the surrounding mid and hindbrain tissue. Studies in different vertebrates show that three parallel signaling pathways, involving Pax2/pax2.1, Wnt1 and Fgf8, are activated independently at this interface during early embryonic stages (Figure $2 \mathrm{C}$ (Canning et al., 2007, Lun and Brand, 1998, Raible and Brand, 2004, Reifers et al., 1998)). During later somitogenesis stages the three pathways become mutually dependent (Rhinn and Brand, 2001). The expression of the region-specific transcription factors is later under the control of Fgf8, 17, 18 and Wnt1, 8b 10, secreted by the isthmic organizer itself (Raible and Brand, 2004, Foucher et al., 2006, Buckles et al., 2004, Lekven et al., 2003 O'Hara, 2005 \#488). These factors are involved in regulating cell proliferation and patterning of the cerebellum as well as cell differentiation and maintenance.

The cerebellar neurons and glia originate from two principal germinal zones in the hindbrain, the rhombic lip (RL) and the ventricular zone (VZ (Wingate, 2001)). Excitatory neurons are generated by the RL and the inhibitory neurons are generated from the VZ (Hoshino et al., 2005). The transcription factor Ptfla marks progenitors of inhibitory neurons in the VZ, while the transcription factor Ato1 labels progenitors for excitatory cells in the RL and subsequent EGL (Ben-Arie et al., 1997, Hoshino et al., 2005). In zebrafish the cerebellar primordium becomes morphologically distinguishable during mid-segmentation stages (Figure $2 \mathrm{~B}$ ). The upper and lower rhombic lip parts are well recognizable one day after fertilization and atohla-b expression is detected in the whole RL (Adolf et al., 2004, Kani et al., Kim et al., 1997, Koster and Fraser, 2001), while ptfla expression is confined to the lower part of the RL (Elsen et al., 2008, Kani et al., Volkmann et al., 2008, Zecchin et al., 2004). The generation of cerebellar neurons starts around two days after fertilization in zebrafish. Initiation of layer formation starts at three days after fertilization when the first differentiated Purkinje cells are 
detected (Bae et al., 2009, Katsuyama et al., 2007, Volkmann et al., 2008). Granule cell production starts at two days after fertilization when granule cell precursors leave the URL(Adolf et al., 2004, Bae et al., 2009, Chaplin et al., Koster and Fraser, 2001, Toyama et al., 2004, Volkmann et al., 2008). They rapidly migrate in chain-like structures over long distance and start to differentiate (Koster and Fraser, 2006, Volkmann et al., 2008). All the three cortical layers can be distinguished five days after fertilization.

Cerebellar progenitor activity and neurogenesis continue into adulthood in zebrafish (Grandel et al., 2006, Kaslin et al., 2009, Kaslin et al., 2013). The adult cerebellar stem cell niche consists of polarized neuroepithelial-like cells that inhabit the dorsal part of the IVth ventricle (Figure 2 E). Produced cells rapidly migrate in a distinct outside-in fashion into the granule cell layer where they differentiate into granule cells. In the adult cerebellum the granule precursors migrate into the granule cell layer within 3 days (Kaslin et al., 2009). Although several subtypes of inhibitory and excitatory cells are found in the zebrafish cerebellum, mainly granule cells are produced in the adult (Kaslin et al., 2013). In amniotes granule cell precursors migrate from the URL to the cerebellar surface where they transiently form a highly proliferative second germinal zone, the external granule layer (EGL). Sonic hedgehog secreted from Purkinje neurons act as the major mitogenic signal for granule precursors in the external granule layer (Dahmane and Ruiz i Altaba, 1999, Wechsler-Reya and Scott, 1999). In contrast to amniotes, sonic hedgehog signaling and a prominent external granule cell layer is lacking in the developing and adult zebrafish cerebellum (Chaplin et al., Kaslin et al., 2009). The advent of a secondary zone of transient amplification (e.g. the external granule cell layer) seems to be an amniote specific developmental adaptation because shark, teleost fish and frogs lack an obvious external granule cell layer (Chaplin et al., Butts et al., 2014a, Butts et al., 2014b). This suggests that neurogenesis and production of granule cells in zebrafish is more likely to be controlled on the level of the primary progenitors (Kaslin et al., 2013).

\section{References}

ADOLF, B., BELliPANNI, G., HUBER, V. \& BALLY-CUIF, L. 2004. atoh1.2 and beta3.1 are two new bHLH-encoding genes expressed in selective precursor cells of the zebrafish anterior hindbrain. Gene Expr Patterns, 5, 35-41.

ALONSO, J. R., AREVALO, R., BRINON, J. G., LARA, J., WERUAGA, E. \& AIJON, J. 1992. Parvalbumin immunoreactive neurons and fibres in the teleost cerebellum. Anat Embryol (Berl), 185, 355-61.

ALTMAN, J. \& BAYER, S. A. 1997. Development of the cerebellar system : in relation to its evolution, structure, and functions, Boca Raton, CRC Press.

BAE, Y. K., KANI, S., SHIMIZU, T., TANABE, K., NOJIMA, H., KIMURA, Y., HIGASHIJIMA, S. \& HIBI, M. 2009. Anatomy of zebrafish cerebellum and screen for mutations affecting its development. Dev Biol, 330, 406-26.

BEDELl, V. M., WANG, Y., CAMPBElL, J. M., POSHUSTA, T. L., STARKER, C. G., KRUG II, R. G., TAN, W., PENHEITER, S. G., MA, A. C., LEUNG, A. Y. H., FAHRENKRUG, S. C., CARLSON, D. F., VOYTAS, D. F., CLARK, K. J., ESSNER, J. J. \& EKKER, S. C. 2012. In vivo genome editing using a high-efficiency TALEN system. Nature, 491, 114-118.

BELL, C. C. 2002. Evolution of cerebellum-like structures. Brain Behav Evol, 59, 312-26.

BELL, C. C., HAN, V. \& SAWTELL, N. B. 2008. Cerebellum-like structures and their implications for cerebellar function. Annu Rev Neurosci, 31, 1-24.

BEN-ARIE, N., BELlen, H. J., ARMStrong, D. L., MCCAll, A. E., GORDADZE, P. R., GUO, Q., MATZUK, M. M. \& ZOGHBI, H. Y. 1997. Math1 is essential for genesis of cerebellar granule neurons. Nature, 390, 169-72.

BRAND, M., HEISENBERG, C. P., JIANG, Y. J., BEUCHLE, D., LUN, K., FURUTANI-SEIKI, M., GRANATO, M., HAFFTER, P., HAMMERSCHMIDT, M., KANE, D. A., KELSH, R. N., MULLINS, M. C., ODENTHAL, J., VAN EEDEN, F. J. \& NUSSLEIN-VOLHARD, C. 1996. Mutations in 
zebrafish genes affecting the formation of the boundary between midbrain and hindbrain. Development, $123,179-90$.

BROCCOLI, V., BONCINELLI, E. \& WURST, W. 1999. The caudal limit of Otx2 expression positions the isthmic organizer. Nature, 401, 164-8.

BUCKLES, G. R., THORPE, C. J., RAMEL, M. C. \& LEKVEN, A. C. 2004. Combinatorial Wnt control of zebrafish midbrain-hindbrain boundary formation. Mech Dev, 121, 437-47.

BUTLER A., B., HODOS W., 2005. Comparative vertebrate neuroanatomy, New York, John Wiley \& Sons.

BUTTS, T., HANZEL, M. \& WINGATE, R. J. 2014a. Transit amplification in the amniote cerebellum evolved via a heterochronic shift in NeuroD1 expression. Development, 141, 2791-5.

BUTTS, T., MODRELL, M. S., BAKER, C. V. \& WINGATE, R. J. 2014b. The evolution of the vertebrate cerebellum: absence of a proliferative external granule layer in a non-teleost ray-finned fish. Evolution \& development, 16, 92-100.

CANNING, C. A., LEE, L., IRVING, C., MASON, I. \& JONES, C. M. 2007. Sustained interactive Wnt and FGF signaling is required to maintain isthmic identity. Dev Biol, 305, 276-86.

CHAPLIN, N., TENDENG, C. \& WINGATE, R. J. 2010. Absence of an external germinal layer in zebrafish and shark reveals a distinct, anamniote ground plan of cerebellum development. $J$ Neurosci, 30, 3048-57.

DAHMANE, N. \& RUIZ I ALTABA, A. 1999. Sonic hedgehog regulates the growth and patterning of the cerebellum. Development, 126, 3089-100.

DELGADO, L. \& SCHMACHTENBERG, O. 2008. Immunohistochemical localization of GABA, GAD65, and the receptor subunits GABAAalpha1 and GABAB1 in the zebrafish cerebellum. Cerebellum, 7, 444-50.

ELSEN, G. E., CHOI, L. Y., MILLEN, K. J., GRINBLAT, Y. \& PRINCE, V. E. 2008. Zic1 and Zic4 regulate zebrafish roof plate specification and hindbrain ventricle morphogenesis. Dev Biol, 314, 376-92.

FINGER, T. E. 1978. Efferent neurons of the teleost cerebellum. Brain Res, 153, 608-14.

FINGER, T. E. 1983. Organization of the teleost cerebellum. In: NORTHCUTT, R. G., DAVIS, R., G., (ed.) Fish neurobiology. University of Michigan press, Ann Arbor.

FOLGUEIRA, M., ANADON, R. \& YANEZ, J. 2006. Afferent and efferent connections of the cerebellum of a salmonid, the rainbow trout (Oncorhynchus mykiss): a tract-tracing study. J Comp Neurol, 497, 542-65.

FOUCHER, I., MIONE, M., SIMEONE, A., ACAMPORA, D., BALlY-CUIF, L. \& HOUART, C. 2006. Differentiation of cerebellar cell identities in absence of Fgf signalling in zebrafish Otx morphants. Development, 133, 1891-900.

GOLL, M. G., ANDERSON, R., STAINIER, D. Y., SPRADling, A. C. \& HALPERN, M. E. 2009. Transcriptional silencing and reactivation in transgenic zebrafish. Genetics, 182, 747-55.

GRANDEL, H., KASLIN, J., GANZ, J., WENZEL, I. \& BRAND, M. 2006. Neural stem cells and neurogenesis in the adult zebrafish brain: origin, proliferation dynamics, migration and cell fate. Dev Biol, 295, 26377.

HANS, S., KASLIN, J., FREUDENREICH, D. \& BRAND, M. 2009. Temporally-controlled site-specific recombination in zebrafish. PLOS ONE, 4, e4640.

HOSHINO, M., NAKAMURA, S., MORI, K., KAWAUCHI, T., TERAO, M., NISHIMURA, Y. V., FUKUDA, A., FUSE, T., MATSUO, N., SONE, M., WATANABE, M., BITO, H., TERASHIMA, T., WRIGHT, C. V., KAWAGUCHI, Y., NAKAO, K. \& NABESHIMA, Y. 2005. Ptfla, a bHLH transcriptional gene, defines GABAergic neuronal fates in cerebellum. Neuron, 47, 201-13.

HUANG, P., XIAO, A., ZHOU, M., ZHU, Z., LIN, S. \& ZHANG, B. 2011. Heritable gene targeting in zebrafish using customized TALENs. Nat Biotech, 29, 699-700.

HWANG, W. Y., FU, Y., REYON, D., MAEDER, M. L., TSAI, S. Q., SANDER, J. D., PETERSON, R. T., YEH, J. R. J. \& JOUNG, J. K. 2013. Efficient genome editing in zebrafish using a CRISPR-Cas system. Nat Biotech, 31, 227-229.

IKENAGA, T., YOSHIDA, M. \& UEMATSU, K. 2002. Efferent connections of the cerebellum of the goldfish, Carassius auratus. Brain Behav Evol, 60, 36-51.

IKENAGA, T., YOSHIDA, M. \& UEMATSU, K. 2005. Morphology and immunohistochemistry of efferent neurons of the goldfish corpus cerebelli. J Comp Neurol, 487, 300-11.

ITO, H. \& YOSHIMOTO, M. 1990. Cytoarchitecture and fiber connections of the nucleus lateralis valvulae in the carp (Cyprinus carpio). J Comp Neurol, 298, 385-99.

KANI, S., BAE, Y. K., ShIMIZU, T., TANABE, K., SATOU, C., PARSONS, M. J., SCOTT, E., HIGASHIJIMA, S. \& HIBI, M. 2010. Proneural gene-linked neurogenesis in zebrafish cerebellum. Dev Biol, 343, 1-17.

KASLIN, J., GANZ, J., GEFFARTH, M., GRANDEL, H., HANS, S. \& BRAND, M. 2009. Stem cells in the adult zebrafish cerebellum: initiation and maintenance of a novel stem cell niche. J Neurosci, 29, 614253.

KASLIN, J., KROEHNE, V., BENATO, F., ARGENTON, F. \& BRAND, M. 2013. Development and specification of cerebellar stem and progenitor cells in zebrafish: from embryo to adult. Neural Dev, 8, 9. 
KATSUYAMA, Y., OOMIYA, Y., DEKIMOTO, H., MOTOOKA, E., TAKANO, A., KIKKAWA, S., HIBI, M. \& TERASHIMA, T. 2007. Expression of zebrafish ROR alpha gene in cerebellar-like structures. Dev Dyn, 236, 2694-701.

KIM, C. H., BAE, Y. K., YAMANAKA, Y., YAMASHITA, S., SHIMIZU, T., FUJI, R., PARK, H. C., YEO, S. Y., HUH, T. L., HIBI, M. \& HIRANO, T. 1997. Overexpression of neurogenin induces ectopic expression of HuC in zebrafish. Neurosci Lett, 239, 113-6.

KOSTER, R. W. \& FRASER, S. E. 2001. Direct imaging of in vivo neuronal migration in the developing cerebellum. Curr Biol, 11, 1858-63.

KOSTER, R. W. \& FRASER, S. E. 2006. FGF signaling mediates regeneration of the differentiating cerebellum through repatterning of the anterior hindbrain and reinitiation of neuronal migration. $J$ Neurosci, 26, 7293-304

LEKVEN, A. C., BUCKLES, G. R., KOSTAKIS, N. \& MOON, R. T. 2003. Wnt1 and wnt10b function redundantly at the zebrafish midbrain-hindbrain boundary. Dev Biol, 254, 172-87.

LUN, K. \& BRAND, M. 1998. A series of no isthmus (noi) alleles of the zebrafish pax2.1 gene reveals multiple signaling events in development of the midbrain-hindbrain boundary. Development, 125, 3049-62.

MATSUI, H., NAMIKAWA, K., BABARYKA, A. \& KOSTER, R. W. 2014. Functional regionalization of the teleost cerebellum analyzed in vivo. Proc Natl Acad Sci U S A, 111, 11846-51.

MEEK, J. 1992. Comparative aspects of cerebellar organization. From mormyrids to mammals. Eur J Morphol, $30,37-51$.

MEEK, J. 1998. Holosteans and teleosts. In: NIEUWENHUYS R., T. D. H., J., NICHOLSON C. (ed.) The central nervous system of vertebrates Berlin: Springer.

MEEK, J., YANG, J. Y., HAN, V. Z. \& BELL, C. C. 2008. Morphological analysis of the mormyrid cerebellum using immunohistochemistry, with emphasis on the unusual neuronal organization of the valvula. $J$ Comp Neurol, 510, 396-421.

MILlET, S., CAMPBElL, K., EPSTEIN, D. J., LOSOS, K., HARRIS, E. \& JOYNER, A. L. 1999. A role for Gbx2 in repression of Otx2 and positioning the mid/hindbrain organizer. Nature, 401, 161-4.

MURAKAMI, T. \& MORITA, Y. 1987. Morphology and distribution of the projection neurons in the cerebellum in a teleost, Sebastiscus marmoratus. J Comp Neurol, 256, 607-23.

NIEUWENHUYS, R., POUWELS, E. \& SMULDERS-KERSTEN, E. 1974. The neuronal organization of cerebellar lobe $\mathrm{C} 1$ in the mormyrid fish Gnathonemus Petersii (teleostei). Z Anat Entwicklungsgesch, 144, 315-36.

RAIBLE, F. \& BRAND, M. 2004. Divide et Impera--the midbrain-hindbrain boundary and its organizer. Trends Neurosci, 27, 727-34

REIFERS, F., BOHLI, H., WALSH, E. C., CROSSLEY, P. H., STAINIER, D. Y. \& BRAND, M. 1998. Fgf8 is mutated in zebrafish acerebellar (ace) mutants and is required for maintenance of midbrain-hindbrain boundary development and somitogenesis. Development, 125, 2381-95.

RHINN, M. \& BRAND, M. 2001. The midbrain--hindbrain boundary organizer. Curr Opin Neurobiol, 11, $34-$ 42.

RHINN, M., LUN, K., AHRENDT, R., GEFFARTH, M. \& BRAND, M. 2009. Zebrafish gbx1 refines the midbrain-hindbrain boundary border and mediates the Wnt8 posteriorization signal. Neural Dev, 4, 12.

RHINN, M., LUN, K., LUZ, M., WERNER, M. \& BRAND, M. 2005. Positioning of the midbrain-hindbrain boundary organizer through global posteriorization of the neuroectoderm mediated by Wnt8 signaling. Development, 132, 1261-72.

SANDER, J. D., CADE, L., KHAYTER, C., REYON, D., PETERSON, R. T., JOUNG, J. K. \& YEH, J.-R. J. 2011. Targeted gene disruption in somatic zebrafish cells using engineered TALENs. Nat Biotech, 29, 697-698.

SCOTT, E. K. 2009. The Gal4/UAS toolbox in zebrafish: new approaches for defining behavioral circuits. $J$ Neurochem, 110, 441-56.

SIMEONE, A. 2000. Positioning the isthmic organizer where Otx2 and Gbx2meet. Trends Genet, 16, 237-40.

SIMMICH, J., STAYKOV, E. \& SCOTT, E. 2012. Zebrafish as an appealing model for optogenetic studies. Progress in brain research, 196, 145-62.

SUSTER, M. L., SUMIYAMA, K. \& KAWAKAMI, K. 2009. Transposon-mediated BAC transgenesis in zebrafish and mice. BMC Genomics, 10, 477.

TOYAMA, R., GOMEZ, D. M., MANA, M. D. \& DAWID, I. B. 2004. Sequence relationships and expression patterns of zebrafish zic2 and zic5 genes. Gene Expr Patterns, 4, 345-50.

VOLKMANN, K., CHEN, Y. Y., HARRIS, M. P., WULliMANN, M. F. \& KOSTER, R. W. 2010. The zebrafish cerebellar upper rhombic lip generates tegmental hindbrain nuclei by long-distance migration in an evolutionary conserved manner. J Comp Neurol, 518, 2794-817.

VOLKMANN, K., RIEGER, S., BABARYKA, A. \& KOSTER, R. W. 2008. The zebrafish cerebellar rhombic lip is spatially patterned in producing granule cell populations of different functional compartments. Dev Biol, 313, 167-80. 
WECHSLER-REYA, R. J. \& SCOTT, M. P. 1999. Control of neuronal precursor proliferation in the cerebellum by Sonic Hedgehog. Neuron, 22, 103-14.

WINGATE, R. J. 2001. The rhombic lip and early cerebellar development. Curr Opin Neurobiol, 11, 82-8.

WULLIMANN, M. F. 1997. The central nervous system. In: EVANS D., H., CLAIBORNE J., B., (ed.) In Physiology of Fishes. Boca Raton: CRC Press.

WULLIMANN, M. F. \& NORTHCUTT, R. G. 1988. Connections of the corpus cerebelli in the green sunfish and the common goldfish: a comparison of perciform and cypriniform teleosts. Brain Behav Evol, 32 , 293-316.

WULliMANN, M. F. \& NORTHCUTT, R. G. 1989. Afferent connections of the valvula cerebelli in two teleosts, the common goldfish and the green sunfish. J Comp Neurol, 289, 554-67.

XUE, H. G., YANG, C. Y. \& YAMAMOTO, N. 2008. Afferent sources to the inferior olive and distribution of the olivocerebellar climbing fibers in cyprinids. J Comp Neurol, 507, 1409-27.

ZECCHIN, E., MAVROPOUlOS, A., DEVOS, N., FILIPPI, A., TISO, N., MEYER, D., PEERS, B., BORTOLUSSI, M. \& ARGENTON, F. 2004. Evolutionary conserved role of ptfla in the specification of exocrine pancreatic fates. Dev Biol, 268, 174-84.
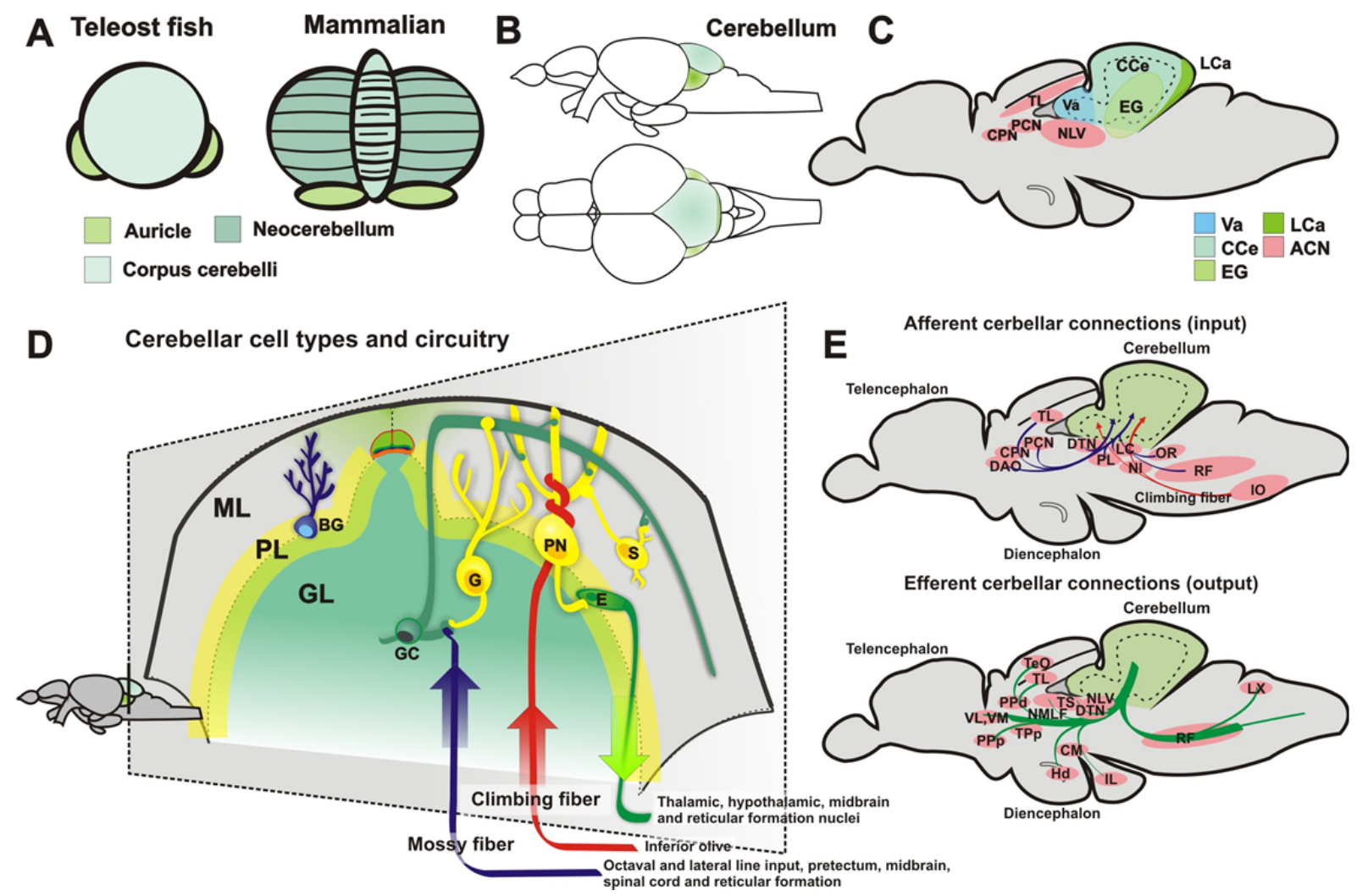

Figure 1. A. The vertebrate cerebellum consists of a major lobe, the corpus cerebelli (cerebellar corpus) and two bilateral lobes, the auricle (flocculus in tetrapods). In addition, mammals display a large lateral expansion of the corpus cerebelli, the neocerebellum. B. Schematic drawing of the zebrafish brain seen from the side and top. Light green illustrates the cerebellar corpus and the darker green the auricle. C. Schematic parasagittal overview of the zebrafish brain showing the major cerebellar parts and associated cerebellar structures. $\mathrm{ACN}=$ accessory cerebellar nuclei, $\mathrm{CCe}=$ cerebellar corpus, $\mathrm{CPN}=$ central pretectal nucleus, $\mathrm{EG}=$ eminentia granularis, $\mathrm{LCa}=$ caudal lobe of cerebellum, $\mathrm{NLV}=$ nucleus lateralis valvulae, $\mathrm{PCN}=$ paracommissural nucleus, $\mathrm{TL}=$ torus longintudinalis, $\mathrm{Va}=$ valvula cerebelli. $\mathrm{D}$. The zebrafish cerebellum has a simple laminar three layered architecture consisting of a molecular layer (ML), purkinje cell layer (PL) and a granule cell layer (GL). The granule layer is consisting of small densely packed excitatory granule cells and inhibitory Golgi neurons $(\mathrm{G})$. The Purkinje cell layer is inhabited with Purkinje neurons (PN), a specialized macroglia type, Bergmann glia (BG) and excitatory eurydendroid cells (E). The ML is mainly consisting of 
nerve fibers and scattered inhibitory stellate cells (S). Mossy and climbing fibers excite Purkinje and granule cells. Granule cell axons provide excitatory input to Purkinje cells and their dendrites as well as the Golgi and stellate cells. Purkinje cells inhibit eurydendroid cells. Eurydendroid cell axons project to various targets outside the cerebellum. Stellate cells provide inhibitory input to the dendrites of Purkinje cells and Golgi cells inhibit granule cells. Dendrites from granule cells together with Golgi cell axons and mossy fiber terminals form a specialized synaptic structure known as the glomerulus. E. Cerebellar afferents and efferents in teleost fish. $\mathrm{CM}=$ mammillary body, $\mathrm{CPN}=$ central pretectal nucleus, $\mathrm{DAO}=$ dorsal accessory optic nucleus, $\mathrm{Hd}=$ dorsal zone of periventricular hypothalamus, $\mathrm{DTN}=$ dorsal tegmental nucleus, $\mathrm{IL}=$ inferior lobe of the hypothalamus, $\mathrm{IO}=$ inferior olive, $\mathrm{LC}=$ locus coeruleus, $\mathrm{LX}=$ vagal lobe, $\mathrm{NI}=$ isthmic nucleus, $\mathrm{NLV}=$ nucleus lateralis valvulae, $\mathrm{NMLF}=$ nucleus of the medial longitudinal fascicle, $\mathrm{OR}=$ octavolateral region, $\mathrm{PCN}=$ paracommissural nucleus, $\mathrm{PPd}=$ dorsal periventricular pretectal nucleus, $\mathrm{PP}=$ posterior parvocellular preoptic nucleus, $\mathrm{RF}=$ reticular formation, $\mathrm{PL}=$ perilemniscal nucleus, $\mathrm{TL}=$ torus longintudinalis, $\mathrm{TS}=$ semicircular torus, $\mathrm{TeO}=$ optic tectum, $\mathrm{TPp}=$ periventricular nucleus of the posterior tuberculum, $\mathrm{VL}=$ ventrolateral thalamic nucleus, $\mathrm{VM}=$ ventromedial thalamic nucleus
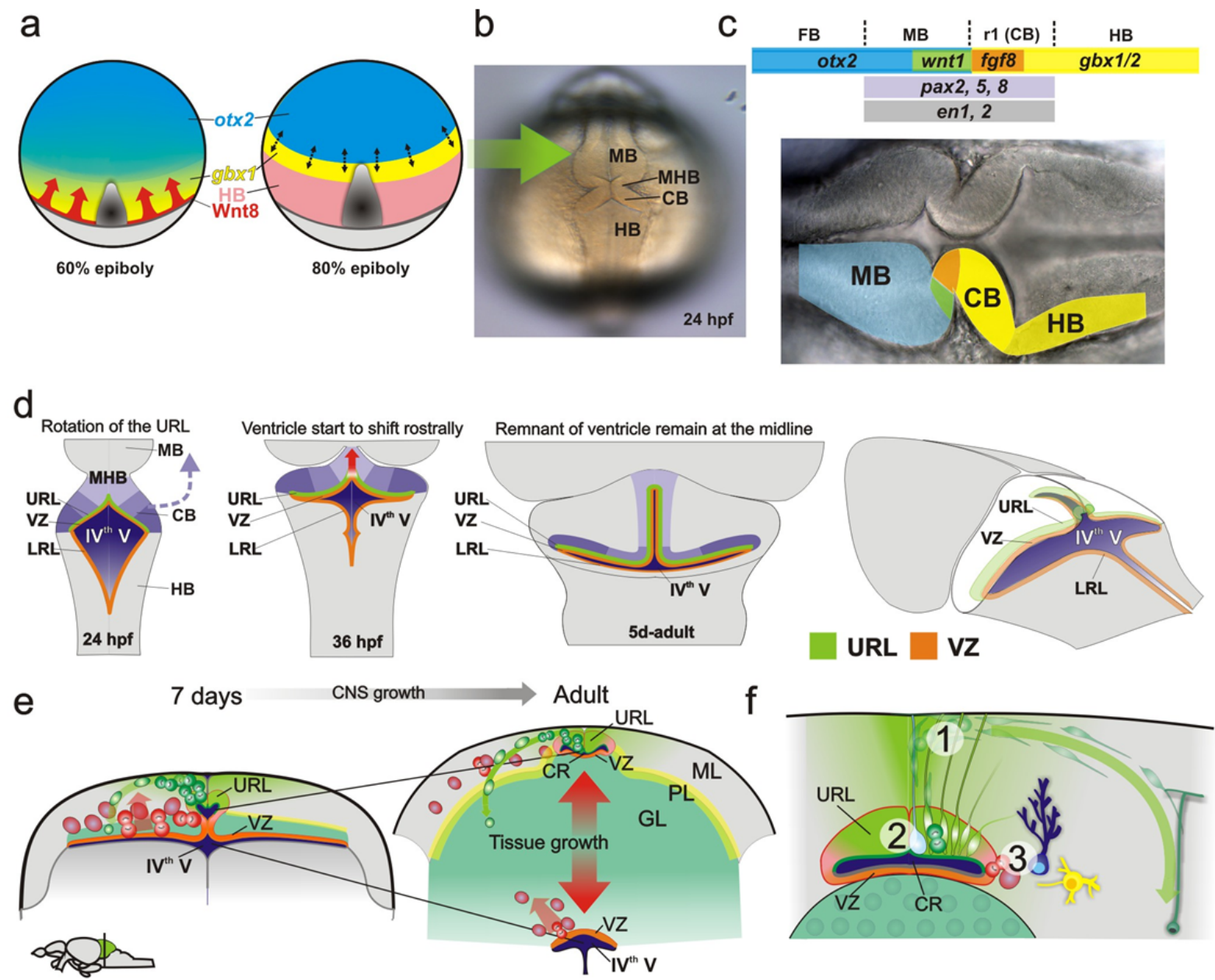

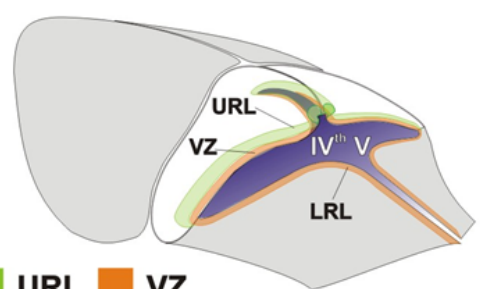

URL VZ

Figure 2. A. Positioning of the midbrain-hindbrain boundary organizer in the neural plate of zebrafish. The interface between cells expressing otx and $g b x$ transcription factors marks the location in the neural plate where the midbrain-hindbrain boundary organizer forms. During gastrulation, Wnt8 is secreted by the blastoderm margin (red arrows). It is required for the initial subdivision of the neuroectoderm, including onset of the posterior gbxl (yellow) expression and establishment of the posterior border of otx2 (blue) expression. Towards the 
end of gastrulation, the otx 2 and gbxl expression domains are sharp and complementary. Grey area $=$ developing axial mesoderm. Light grey=yolk. Black arrows incdicate the mutually repressive interactions. B-C. Morphogenetic events of the cerebellar primordium. At $24 \mathrm{hpf}$ the midbrain-hindbrain boundary, midbrain structures and the cerebellar primordium are clearly distinguishable in the zebrafish embryo. C. At the end of gastrulation, a complex genetic network with several region-specific transcription factors and the secreted molecules Wnt1 and Fgf8 are expressed at the otx/gbx interface. The secreted signals from the isthmic organizer in turn determine the development of the surrounding mid and hindbrain tissue. $\mathbf{D}$. Summary of the early morphogenetic events and the establishment of the progenitor domains. There is a morphogenetic rotation of the cerebellar primordium (blue arrow). From $36 \mathrm{hpf}$ onwards the dorsomedial part of the IVth ventricle is shifted anteriorly creating a dorsomedial extension of the IVth ventricle (red arrow). Ventricularly located progenitors (orange line) are found in the LRL of the hindbrain and in the VZ of the cerebellum. Cerebellar progenitors adjacent to the roof plate are induced to turn in to granule cell progenitors (URL, green line). (e). Schematic summary of tissue growth and displacement of the progenitor niche. Displacement of the URL progenitor niche through tissue growth begins around $7 \mathrm{dpf}$. During juvenile stages there is vast generation of granule cells and massive expansion of the granule cell layer. URL progenitors (green) are maintained dorsal to the cerebellar recesus in adult zebrafish while ventricular zone derived progenitors and glia (orange) are found ventral to the recessus around the $\mathrm{IV}^{\text {th }}$ ventricle. (f) Schematic summary of the zebrafish cerebellar progenitor niche. Neural progenitors derived from the URL are maintained in the dorsomedial part of the cerebellum around a remnant of the IVth ventricle (the cerebellar recessuss). These progenitors give rise to granule neurons in a distinct outside-in fashion. 1. Polarized neuroepithelial-like progenitors (green) are restricted to the midline of the dorsal cerebellum. The progenitors give rise to rapidly migrating granule precursors (dark green) that initially migrate dorsolaterally. During this initial phase the granule precursors still may proliferate. After reaching the meninge the granule precursors change to a unipolar morphology and start to migrate in ventrolateral direction towards the GL. The granule precursors migrate into the GL and differentiate in to granule neurons. 2. A few glia with a radial morphology (light blue) are found close to the midline and they are used as scaffolds during the initial dorsal migration of granule precursors. 3. Bergmann glia-like cells are interspersed in the PL (dark blue). A low amount of Bergmann glia-like cells and inhibitory neurons (yellow) are generated from VZ progenitors that are found lateral and ventral to the progenitor niche. $\mathrm{VZ}$ progenitors are also found ventrally around the $\mathrm{IV}^{\text {th }}$ ventricle (see E). $C B=$ cerebellar primordium, $H B=$ hindbrain, $G L=$ granule cell layer, $I V^{\text {th }} V=I^{\text {th }}$ ventricle, $\mathrm{LRL}=$ lower rhombic lip, $\mathrm{MHB}=$ midbrain-hindbrain boundary, $\mathrm{ML}=$ molecular layer, $\mathrm{PL}=$ Purkinje cell layer, $\mathrm{URL}=$ upper rhombic lip, $\mathrm{VZ}=$ =entricular zone 